\title{
New County Records For The Northern Curlytail Lizard, Leiocephalus carinatus Gray 1827 (Leiocephalidae), and African Rainbow Lizard, Agama agama complex (Agamidae), in Florida
}

\author{
Laurence L. Connor ${ }^{1}$, Kenneth L. Krysko ${ }^{2}$, Timothy Bourdreau ${ }^{3}$, Jamie S. Roselius ${ }^{4}$, and Richard A. Coon ${ }^{5}$ \\ ${ }^{1}$ Florida Fish and Wildlife Conservation Commission, 601 West Woodward Avenue, Eustis, Florida 32726, USA (larry.connor@myfwc.com) \\ ${ }^{2}$ Florida Museum of Natural History, University of Florida, Gainesville, Florida 32611, USA (kenneyk@ufl.edu) \\ 32791 Oyster Creek Drive, Grove City, Florida 34224, USA (timothy1825@gmail.com) \\ ${ }^{4} 621$ Kentia Road, Casselberry, Florida 32707, USA (jamie.shiner.roselius@gmail.com) \\ 54718 Dovehill Dr, Palm Beach Gardens, Florida 33418, USA (2fromtheprairie@att.net)
}

$\mathrm{T}$ he Northern Curlytail Lizard, Leiocephalus carinatus Gray 1827 , is indigenous to the Bahamas, Cuba, and other northern Caribbean islands (Schwartz 1959a, b; Schwartz and Thomas 1975; Schwartz and Henderson 1991). In the 1940s, this species was intentionally introduced in Palm Beach County, Florida, USA, to control insect pests in sugar cane fields, and it was later introduced to many other areas, which likely resulted in established populations in all directions (King 1960, Weigl et al. 1969, Crowder 1974). The African Rainbow Lizard (Agama agama complex) is indigenous to a broad area of Africa from Mauritania east to Sudan and south to Angola and Tanzania (Spawls et al. 2002). African Rainbow Lizards initially were introduced in Miami in the 1970s; however, this population was extirpated during extensive demolition and construction in the area (Wilson and Porras 1983). Subsequent illegal introductions have led to established populations in Monroe, Miami-Dade, Charlotte, Martin, St. Lucie, Lee, Seminole, and Duval counties (Krysko

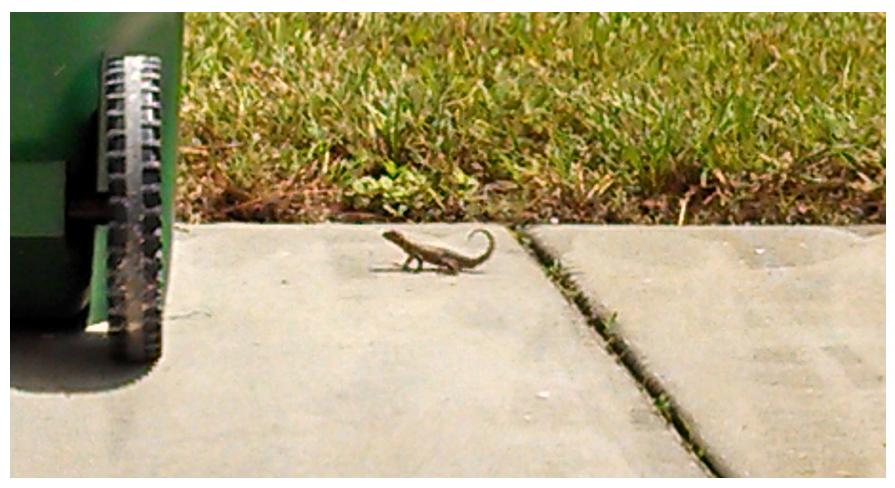

Fig. 1. In situ photograph of a Northern Curlytail Lizard, Leiocephalus carinatus (UF-Herpetology 170991) in Grove City, Charlotte County, Florida, on 24 July 2013. Photograph by Timothy Bourdreau.

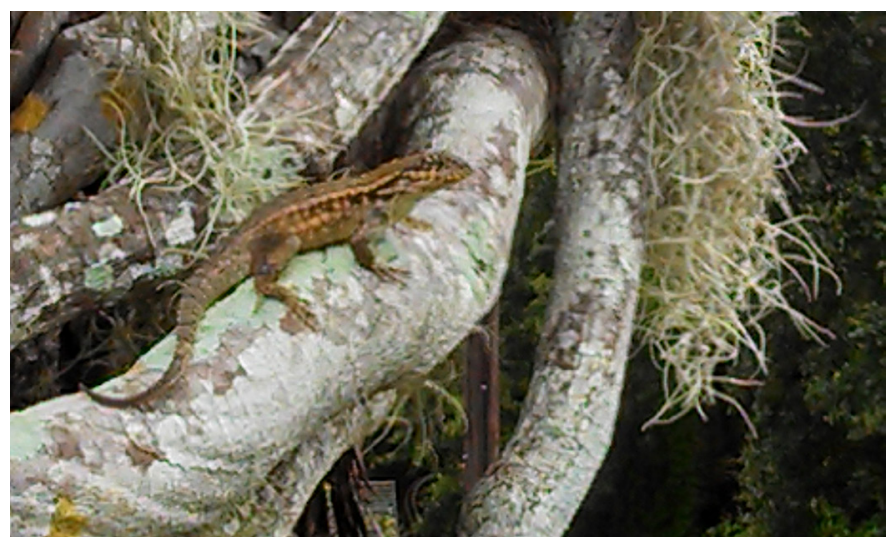

Fig. 2. In situ photograph of a Northern Curlytail Lizard, Leiocephalus carinatus (UF-Herpetology 170992) in Grove City, Charlotte County, Florida, on 25 July 2013. Photograph by Timothy Bourdreau.

et al. 2011). Although this species in Florida was previously identified as $A$. a. africana using morphology and color pattern (Enge et al. 2004), DNA analyses will be necessary to determine the genetic identity of these introduced populations following the recent taxonomic revision proposed by Mediannikov et al. (2012), in which they elevated A. a. africana to full-species status. Herein, we document new county records and possible range expansions for these species.

On 24 July 2013 at 1509 h, TB photographed a Leiocephalus carinatus (photographic voucher UF-Herpetology 170991; Fig. 1) on a concrete driveway at 2791 Oyster Creek Drive, Grove City, Charlotte County, Florida $\left(26.91641^{\circ} \mathrm{N}\right.$, $82.32152^{\circ} \mathrm{W}$, Datum WGS84, 3 m elevation). On 25 July 2013 at $1208 \mathrm{~h}, \mathrm{~TB}$ photographed a second L. carinatus (photographic voucher UF-Herpetology 170992; Fig. 2) at the same location. These are the first vouchered records for 
Charlotte County and are $46.9 \mathrm{~km}$ northwest of the closest known voucher (UF-Herpetology 153370) south of Charlotte Harbor in Lee County (Krysko et al. 2011). On 26 July 2013 at $957 \mathrm{~h}$, JSR photographed a L. carinatus (photographic voucher UF-Herpetology 170737; Fig. 3) at 621 Kentia Road, Casselberry, Seminole County, Florida $\left(28.65509^{\circ} \mathrm{N}\right.$, $81.32216^{\circ} \mathrm{W}, 22 \mathrm{~m}$ elevation). This is the first vouchered record from Seminole County and is $29.6 \mathrm{~km}$ northeast of the closest known voucher (UF-Herpetology 140495) in Orange County (Krysko et al. 2011).

On 19 June 2013, RAC photographed an adult male of the Agama agama complex (photographic voucher UF-Herpetology 170960; Fig. 4) at 4718 Dovehill Drive, Palm Beach Gardens, Palm Beach County, Florida $\left(26.86917^{\circ} \mathrm{N}, 80.10678^{\circ} \mathrm{W}, 4 \mathrm{~m}\right.$ elevation). This is the first vouchered record for Palm Beach County and is 21.7 $\mathrm{km}$ south of the closest known voucher (UF-Herpetology 165583) in Martin County (Krysko et al. 2011). Previously, LLC received two reports of African Rainbow Lizards in Palm Beach County. The first was on 22 August 2011 in Lake Worth $\left(26.61772^{\circ} \mathrm{N}, 80.10938^{\circ} \mathrm{W}\right), 27.9 \mathrm{~km}$ south of the Dovehill Drive location. The second was on 31 May 2013 at the Pratt \& Whitney facility on State Road $710\left(26.90483^{\circ} \mathrm{N}\right.$, $\left.80.30599^{\circ} \mathrm{W}\right), 20.2 \mathrm{~km}$ west of the Dovehill Drive location. Neither report was documented or confirmed; however, in both cases the reporters provided extremely accurate descriptions of adult male African Rainbow Lizards in typical vivid breeding coloration.

Whether these new county records represent new introductions, initial discoveries of existing populations, or range expansion from nearby sites is unclear. Leiocephalus carinatus is somewhat cryptic and could escape detection. However, the area in Orange and Seminole counties is heavily urbanized and the Fish and Wildlife Conservation Commission (FWC) and Florida Museum of Natural History (FLMNH) have received

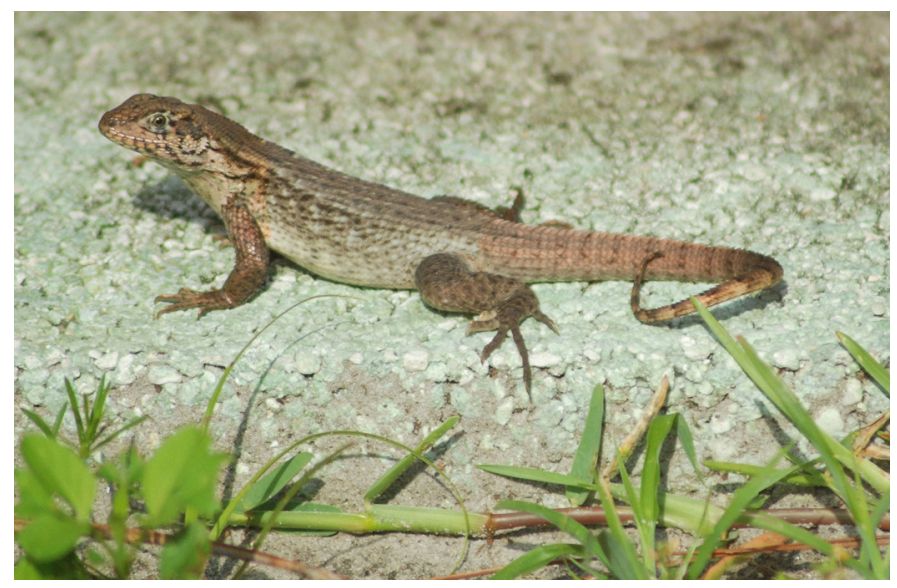

Fig. 3. In situ photograph of a Northern Curlytail Lizard, Leiocephalus carinatus (UF-Herpetology 170737) in Casselberry, Seminole County, Florida, on 26 July 2013. Photograph by Jamie S. Roselius.

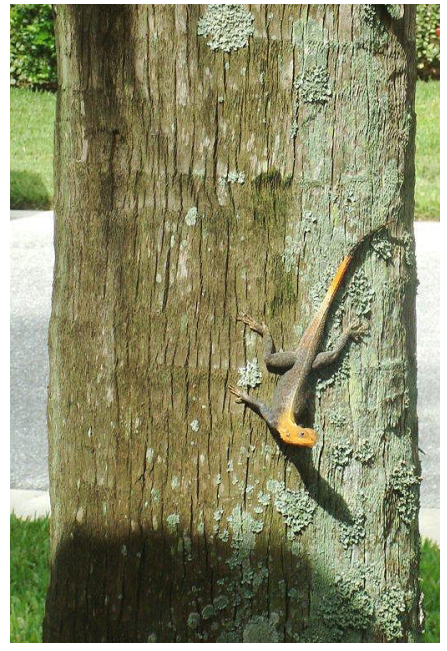

Fig. 4. In situ photograph of a male African Rainbow Lizard, Agama agama africana (UF-Herpetology 170960) in Palm Beach Gardens, Palm Beach County, Florida, on 19 June 2013. Photograph by Richard A. Coon. no reports from areas between the Orange and Seminole county records. The Grove City location is separated from the closest known location by close to $50 \mathrm{~km}$ and a major estuary. Although other sources cannot be ruled out, these records might be detections of new established populations.

Because of the striking coloration of adult male African Rainbow Lizards, this species is less likely to escape detection. The FWC and FLMNH receive numerous reports of these lizards from areas where they are already known to be established. The area between the Dovehill Drive and Pratt $\&$ Whitney locations and the Martin County population is relatively lightly developed by southern Florida standards and has large tracts of conservation lands. This could reduce the likelihood of the species being observed in the intermediate zone. Additionally, the Pratt \& Whitney site is a fairly isolated commercial location that would appear to be an unlikely candidate for a released or escaped pet. Our new African Rainbow Lizards locations could represent a range expansion of the Martin County population.

\section{Acknowledgments}

We thank Dr. Max A. Nickerson and Kevin M. Enge for species confirmation; Gad Perry and Robert Powell for helpful comments on this paper.

\section{Literature Cited}

Crowder, J.P. 1974. The exotic vertebrates of south Florida. South Florida Environmental Project Ecological Report No. DI-SFEP-74-30, Bureau of Sport Fisheries and Wildlife PB-235 214, U.S. Department of the Interior, Atlanta, Georgia.

Enge, K.M., K.L Krysko, and B.L. Talley. 2004. Distribution and ecology of the introduced African Rainbow Lizard, Agama agama africana (Sauria: Agamidae), in Florida. Florida Scientist 67:303-310.

King, F.W. 1960. New populations of West Indian reptiles and amphibians in southeastern Florida. Quarterly Journal of the Florida Academy of Sciences 23:71-73.

Krysko, K.L., K.M. Enge, and P.E. Moler. 2011. Atlas of Amphibians and Reptiles in Florida. Final Report, Project Agreement 08013, Florida Fish and Wildlife Conservation Commission, Tallahassee. 
Mediannikov, O., S. Trape, and J.F. Trape. 2012. A molecular study of the genus Agama (Squamata: Agamidae) in West Africa, with description of two new species and a review of the taxonomy, geographic distribution, and ecology of currently recognized species. Russian Journal of Herpetology 19:115-142.

Schwartz, A. 1959a. Variation in lizards of the Leiocephalus cubensis complex in Cuba and the Isla de Pinos. Bulletin of the Florida State Museum, Biological Sciences 4:97-143.

Schwartz, A. 1959b. The Cuban lizards of the species Leiocephalus carinatus (Gray). Reading Public Museum and Art Gallery, Scientific Publication 10:1-47.

Schwartz, A. and R.W. Henderson. 1991. Amphibians and Reptiles of the West Indies: Descriptions, Distributions, and Natural History. University of Florida
Press, Gainesville, Florida.

Schwartz, A. and R. Thomas. 1975. A check-list of West Indian amphibians and reptiles. Carnegie Museum of Natural History, Special Publication (1):1-216.

Spawls, S., K. Howell, R. Drewes, and J. Ashe. 2002. A Field Guide to the Reptiles of East Africa. Academic Press, San Diego, California.

Weigl, G.L., R.G. Domey, and W.R. Courtenay, Jr. 1969. Survival and range expansion of the Curly-tailed Lizard, Leiocephalus carinatus armouri, in Florida. Copeia 1969:841-842.

Wilson, L.D. and L. Porras. 1983. The ecological impact of man on the south Florida herpetofauna. University of Kansas Museum of Natural History, Special Publication (9):vi +89 pp. 